\title{
"Other Students Always Used to Say, 'Look at the Dykes"' $\uparrow:$ Protecting Students from Peer Sexual Orientation Harassment
}

\author{
Amy Lovell
}

Student-to-student sexual orientation harassment is a serious problem; it harms, often severely, a considerable number of students. Existing laws, however, fail to address this problem adequately. Some laws currently ban discrimination based on sexual orientation, but these laws have been applied only in a minority of jurisdictions to date. Laws prohibiting discrimination based on sex are more common. Although these laws, properly interpreted, should provide protection to victims of sexual orientation harassment, most courts have refused to interpret sex discrimination laws in this fashion. Additionally, even if courts applied sex discrimination laws to student-to-student sexual orientation harassment, these laws, like current laws that ban discrimination based on sexual orientation, provide only incomplete protection to students subject to harassment. Current laws afford relief only when the victim of harassment is able to demonstrate that the school and/or harasser acted or failed to act specifically by referring to the victim's sexual orientation and making a decision based on that sexual orientation. Because student-to-student sexual orientation harassment occurs and causes harm even when the school's and/or the harasser's motivation for acting or failing to act is something other than the victim's sexual orientation, existing laws, including sex discrimination laws, are too narrow with respect to the scope of protection that they provide. Because of this gap in protection, this Comment proposes a statute that comprehensively addresses student-to-student sexual orientation harassment. This Comment argues that the slightly increased responsibility that the proposed statute places on schools is fully justified by the need to prevent

Copyright $@ 1998$ California Law Review, Inc.

$\dagger$ JAMES T. SEARS, Growing Up GAY IN THE South 152 (1991).

J.D. candidate 1998, Boalt Hall School of Law, University of California, Berkeley. 1 thank Professor Kristin Luker, Sharon Bunzel, Doni Gewirtzman, and all of the editors of the California Law Review for their inspiration, direction, criticism, and hard work. 
student-to-student sexual orientation harassment and its negative effects.

\section{INTRODUCTION}

Gay, lesbian, and bisexual students are frequently harassed and physically abused by their classmates. Despite the oftentimes severe nature of this harassment, schools commonly fail to provide protection to these students through negligence, tacit approval of the harassing students' behavior, or their own discriminatory decision-making processes. ${ }^{1}$ Studies demonstrate that sexual orientation harassment often causes or contributes to truancy, substance abuse, suicide, and other negative consequences.

Some legal remedies are presently available to students subject to sexual orientation harassment, but they are limited in their scope and appear to be available only in a minority of jurisdictions. Most existing constitutional and statutory provisions require students to show that the harasser and/or the school acted or failed to act because of certain enumerated characteristics, such as sex. Under these laws, most courts have refused to interpret prohibitions against sex discrimination as encompassing discrimination based on sexual orientation, despite the fact that proper legal analysis mandates such an interpretation of sex discrionination law. For these reasons, victims of sexual orientation harassment are often unable to secure legal relief.

To remedy the difficulties that gay, lesbian, and bisexual students encounter in attempting to secure protection, legislatures should adopt statutes that not only prohibit discrimination based on sexual orientation, but also that affirmatively require schools to address and prevent sexual orientation harassment. These statutes should focus not on the harasser's or the school's motivation, but on the harassing conduct itself and the harm that it causes. Such laws would serve several purposes, including preventimg the negative consequences associated with sexual orientation harassment and correcting the illegitimate judicial constructions of existing sex discrimination statutes.

Part I of this Cominent examines the problem of student-to-student sexual orientation harassment. It presents examples of such harassment, reviews studies to determine the frequency of this harassment, and details the harassment's negative consequences. This Part concludes that peer sexual orientation harassment is widespread and adversely affects a considerable number of students.

1. See Nabozny v. Podlesny, 92 F.3d 446, 451 (7th Cir. 1996) (reporting school principal's statement to student victim of harassment that if student was going to be openly gay, "he should 'expect' such behavior from his fellow students"). 
Part II discusses current laws that may provide a remedy to students who are harassed because of their sexual orientation. These constitutional and statutory provisions, including the Equal Protection Clause and state statutes, may be extremely helpful in securing protection for gay, lesbian, and bisexual students who are harassed. However, these laws fail to provide complete protection because they all impose an intent requirement. This requiremeut mandates that students show that they were harassed and could not secure protection because of their sexual orientation.

Part III discusses sex discrimination laws and explains why students who experience peer sexual orientation harassment may also be able to use these laws to secure relief. In particular, this Part argues that sexual orientation discrimination constitutes sex discrimination and thus, when students are harassed because of their sexual orientation, sex discrimination laws should apply. Under this reasoning, Title IX, which prohibits sex-based discrimination in education, should encompass claims of student-to-student sexual orientation harassment. Courts, however, have largely refused to apply Title IX in this manner.

Because current laws provide only partial protection to students subject to peer sexual orientation harassment, Part IV proposes a statute to comprehensively address sexual orientation harassment. it also provides an overview of the statute. Part V compares the proposed statute to existing constitutional and statutory provisions that provide limited legal remedies to gay, lesbian, and bisexual students who experience harassment. An important difference between existing laws and the proposed statute is that the proposed statute does not impose an intent requirement. Unlike most existing laws, which prohibit harassment only when it is motivated by certain characteristics of the student victim, the proposed statute requires that schools act to remedy harassment when they know or reasonably should know about the peer sexual orientation harassment. Neither the harasser's nor the school's motivations are relevant to determining whether the school has an obligation to take reasonable steps to remedy the harassment. This Part also argues that an intent requirement is inappropriate in the context of peer sexual orientation harassment because it fails to afford sufficient protection for students. The proposed statute recoguizes the limitations im current law and is crafted to avoid providing underinclusive remedies.

Part VI argues that the more expansive scope of the proposed statute is justified. The proposed statute imposes only a slightly greater burden than employers currently face in regard to sexual harassment. The proposed statute's additional requirements are justified by the extreme negative cousequences of peer sexual orientation harassment regardless of the harasser's and/or the school's motivation. This Part also 
emphasizes that the theory underlying the proposed statute is consistent with prior civil rights litigation. Finally, Part VII comments on the prospects of convincing legislatures and/or school boards to adopt this Comment's proposal.

I

\section{Student-to-Student SeXual Orientation HaRassment: EXAMPLES, FREQUENCY, AND EFFECTS}

Student-to-student sexual orientation harassinent is a serious problem. Both in terms of the number of students that it affects and in the severity of the problems that it causes, this harassment is too destructive to be ignored. This Part provides details about student-to-student sexual orientation harassment, including furnishing statistics on the number of students affected and on the negative consequences caused by such harassinent.

\section{A. Examples and Frequency}

While attending middle school and high school, classmates continually subjected Jamie Nabozny to verbal and physical harassment concerning his sexual orientation. ${ }^{2}$ Nabozny's classmates often called him "faggot" and "queer," struck him, and spit on him. ${ }^{3}$ During one attack, two male students "held Nabozny down and performed a inock rape on Nabozny, exclaiming that [he] should enjoy it." 4 Later, two male students comered Nabozny in the bathroom, hit him, and urinated on him..$^{5}$

In high school, Olivia had a lesbian relationship with Kris. A friend of Olivia's warned her that if she wanted to avoid other students talking about her relationship with Kris, Olivia should change the way in which she acted around Kris. Shortly thereafter, Olivia began to see comments such as "Olivia and Kris are lezzie,' and 'Kris and Olivia like to fuck with dildos" "scribbled on the back of the chairs in one classrooin. ${ }^{6}$

These and numerous other reports by individual adolescents ${ }^{7}$ suggest that peer sexual orientation harassinent may be common. Statistics

\footnotetext{
2. See id. at 449 .

3. See id. at 451-52.

4. Id. at 451.

5. See id. at 452 .

6. JAMES T. SEARS, GROWNG UP GAY IN THE SOUTH 305 (1991).
}

7. See id. at $\mathbf{5 1}$ (recounting story of male student who classmates called "fag" every day on school bus); id. at 152 (relating experiences of group of lesbian and gay high school students repeatedly called "dykes and queers" by other students); id. at 344 (describing how junior high school students often made remarks to male classmate such as, "I hear you suck dicks"); A. Damien Martin \& Emery S. Hetrick, The Stigmatization of the Gay and Lesbian Adolescent, J. HOMOSEXUALITY, Nos. 1/2,1988, at 163, 170 (describing experience of 15-year-old who confided in friend that he might be gay and subsequently left school due to ensuing harassment); Andrew Kirtzman, Gay Teens 
derived from samples of larger groups of students confirm this suspicion. Although there is a general lack of data on the subject, the existing studies demonstrate that a significant number of students experience harassment that focuses on their actual or perceived sexual orientation. ${ }^{8}$

Studies have assessed the prevalence of sexual orientation harassment in two ways. The first is through surveys of randomly selected groups of all students, not limited to students who identify themselves as lesbian, gay, or bisexual. This method is the most direct way to determine how frequently sexual orientation harassment occurs. It also accounts for incidents in which heterosexual students who are thought to be gay by their classinates experience sexual orientation harassment.

Under this method, one 1993 study questioned more than 1,600 students in seventy-nine junior and senior high schools across the United States. ${ }^{9}$ This survey did not target students of any particular sexual orientation. Additionally, the study contained "representative samples for Hispanic, white, and African American students."10 The study reported that seventeen percent of all of the students questioned had been called "gay" or "lesbian" when they did not want to be. ${ }^{11}$ Thus, sexual orientation harassment in our schools affects a sizable number of students nationwide:

A second method to determine the prevalence of sexual orientation harassment is to review studies that report the percentage of students who are gay, lesbian, and bisexual. This method then considers reports that sample gay, lesbian, and bisexual students concerning harassment. By ascertaining the number of gay, lesbian, and bisexual students, and then determining what percentage of those students are harassed, it is possible to obtain an estimate of how widespread sexual orientation harassment is in schools. This method is more problematic than the first because it involves reviewing two different types of surveys of students who are generally hard to reach. ${ }^{12}$ In addition, it underestimates the frequency of sexual orientation harassment because it does not account for those heterosexual students who are nevertheless harassed about sexual

Harassed in N.Y. Schools: Advocates Say Homophobia is Last Form of Intolerance Allowed to Flourish, ATLANTA J. \& CONST., May 5, 1992, at D6 (describing scene in which eleventh-grader was called "faggot" and was later attacked by four classmates).

8. See infra notes 9-11, 13-22 and accompanying text.

9. See American Ass' n of Univ. Women Educ. Found., Hostile Hallways 5 (1993).

10. Id.

11. See id. at 10.

12. See Willie J. Edwards, A Sociological Analysis of an In Visible Minority Group: Male Adolescent Homosexuals, 27 YouTH \& Soc'y 334, 340 (1996) (explaining that it is "extremely difficult to obtain large samples of gay adolescents, especially Black males, who are not attending some type of therapeutic or support group, because most fear disclosure"); Curtis D. Proctor \& Victor K. Groze, Risk Factors for Suicide among Gay, Lesbian, and Bisexual Youths, 39 Soc. WoRK 504, 508 (1994) (stating that there is no avenue to reach gay, lesbian, and bisexual youths who live in rural areas). 
orientation due to their classmates' perceptions. Despite these limitations, this method is useful, especially given the lack of data on the issue.

In regard to the first step of this second method-determining what percentage of students are lesbian, gay, or bisexual-one survey questioned more than 36,000 students in Minnesota in grades seven through twelve. ${ }^{13}$ The study reported that $1.4 \%$ described themselves as homosexual or bisexual, ${ }^{14}$ and $10.7 \%$ described themselves as being "unsure" of their sexual orientation. ${ }^{15}$ Additionally, $4.5 \%$ of the total sample reported that they were attracted primarily to members of their own sex..$^{16}$ Other sources also indicate that a considerable number of teenagers are lesbian, gay, or bisexual. ${ }^{17}$

With respect to the second step of the second method-sampling what percentage of gay, lesbian, and bisexual students are harassed"[t]he National Gay Task Force, in a nationwide survey, found that 45 percent of gay males and nearly $20 \%$ of lesbians had experienced verbal or physical assault in secondary schools." 18 In another survey of gay and bisexual male adolescents, over one-half of the subjects "had been ridiculed because of their sexuality, usually by peers."19 A study of twenty-nime gay and bisexual male youths revealed that thirty percent of these adolescents "were victims of physical assaults, one half of which occurred on school property." 20 Additionally, over one-half of

13. See Gary Remafedi et al., Demography of Sexual Orientation in Adolescents, 89 Pediatrics 714, 714 (1992).

14. See id. at 719.

15. See id. at 716 .

16. See id. One might expect the percentages of students identifying themselves as homosexual or bisexual to match those reporting that they were primarily attracted to members of the same sex. The different ways that some teenagers view behavior, identity, and orientation help explain these disparities. For example, some adolescents engage in sexual behavior with members of the same sex, but nevertheless define themselves as heterosexual. Other teenagers consider themselves gay, lesbian, or bisexual but may not have had any sexual contact with members of the same sex. See Ritch C. Savin-Williams, Gay and Lesbian Adolescents, MARrIAGE \& FAM. Rev., Nos. 3/4, 1989 at 197, 201.

17. See, e.g., Donna I. Dennis \& Ruth E. Harlow, Gay Youth and the Right to Education, 4 YALE L. \& POL'Y REV. 446, 446 n.1 (1986) (stating that there are approximately 150,000 gay and lesbian teenagers in the New York City metropolitan area, 10,000 lesbian and gay students in Philadelphia public high schools, and 24,000 gay or lesbian teenagers in the District of Columbia); Leo Treadway \& John Yoakam, Creating a Safer School Environment for Lesbian and Gay Students, $62 \mathrm{~J}$. SCH. HEALTH 352, 352 (1992) (stating that homosexual youth account for "up to $10 \%$ of the youth population").

18. Paul Gibson, Gay Male and Lesbian Youth Suicide, in 3 Alcohol, DRUG ABUSE, AND Mental Health AdMin., U.S. DEP'T OF HEALTH \& HUMAN SERVS., REPORT OF THE SECRETARY'S TASKFORCE ON Y OUTH SUICIDE 110, 112 (Marcia R. Feinleb ed., 1989).

19. Ritch C. Savin-Williams, Verbal and Physical Abuse as Stressors in the Lives of Lesbian, Gay Male, and Bisexual Youths: Associations with School Problems, Running Away, Substance Abuse, Prostitution, and Suicide, 62 J. CONSULTING \& CLINICAL PSYCHOL. 261, 263 (1994).

20. Id. 
the participants of this study also reported "regular verbal abuse from classmates."21 Finally, in a study of thirty-seven African-American gay and bisexual male adolescents, $66 \%$ of the respondents reported that they "had been harassed by someone who suspected them to be homosexual." 22

These studies show that a substantial percentage of queer ${ }^{23}$ youth are harassed in regard to their sexual orientation. This fact, combined with the finding that numerous youths are lesbian, gay, or bisexual, suggests that student-to-student sexual orientation harassment is a frequent occurrence in American schools.

\section{B. Effects of Harassment on Lesbian, Gay, and Bisexual Students}

Reports from individual students hint at the severe consequences of sexual orientation harassment. For example, the harassment that Jamie Nabozny experienced in junior high and high school drove him to repeatedly attempt suicide, to run away, and finally to leave home to attend another school in a different city. ${ }^{24}$ Once Ohvia began to see derogatory comments concerning her sexual relationship with another female student scribbled on the backs of chairs in one class, she withdrew from that class to stop the rumors from spreading. ${ }^{25}$ Additionally, she and her girlfriend were more aloof toward each other in public and Olivia began dating boys, sometimes engaging in sexual behavior with them, "purely for show."26

Undoubtedly, not all harassment of gay, lesbian, and bisexual students results in such dire consequences. Indeed, "[ $t]$ here is great diversity among gay and lesbian youth in receiving and responding to peer ridicule." 27 Nonetheless, studies indicate that harassment has a negative effect on a substantial number of queer students. ${ }^{28}$ Before discussing these findings, I will address two criticisms made in connection with these studies.

First, some believe that peer harassment does not harm gay, lesbian, and bisexual students. Instead, according to this view, the true root of any harm is the student's "abnormal" sexual orientation, independent

21. Id.

22. Edwards, supra note 12 , at 343 .

23. I use the word "queer" as a synonym to the terms "lesbian", "gay", and "bisexual". I, of course, use the term non-pejoratively in an attempt to reclaim it.

24. See Nabozny v. Podlesny, 92 F.3d 446, 452 (7th Cir. 1996).

25. See SEARS, supra note 6 , at 305 .

26. Id. at 305-06.

27. Ritch C. Savin-Williams, Reactions of Gay and Lesbian Youth to Verbal and Physical Harassment, HUM. ECOLOGY F., Winter 1990, at 12, 12.

28. See infra text accompanying notes 35-64. 
of any outside stressors. ${ }^{29}$ This view posits that gay, lesbian, and bisexual students are inherently susceptible to self-destructive and harmful behavior. Put another way, this notion maintains that homosexuality itself causes or is at least symptomatic of psychological problems. However, this perception is erroneous. Numerous studies have demonstrated that the psychological and other difficulties that gay, lesbian, and bisexual students experience are the result of a school-based culture that expresses disapproval and oftentimes extreme hostility toward apparently nonmajoritarian sexual orientations. ${ }^{30}$

Second, some commentators are concerned that studies showing high rates of suicide among lesbian, gay, and bisexual students are overly pessimistic and are based on unrepresentative student samples. ${ }^{31}$ As a result, a few authors have consciously strived to demonstrate that queer students are capable of functioning well, even when faced with

29. See Gibson, supra note 18 , at 130 (explaining and criticizing idea that a "youth's gay orientation is the source of the problem rather than the response of others to his/her being lesbian or gay").

30. See John C. Gonsiorek, Mental Health Issues of Gay and Lesbian Adolescents, in PSYCHOLOGICAL PERSPECTIVES ON LESBIAN AND GAY MALE EXPERIENCES 469, 473 (Linda D. Gamets \& Douglas C. Kimmel eds., 1993).
Although it is difficult to distinguish external stressors from the psychological events they mobilize, it is important to note that many of the problems that are experienced by gay and lesbian youth appear to be psychological or intrapsychic in nature, but actually stem from external stress and lack of support. Verbal and physical abuse from peers is one of the most obvious stressors.

Id.; Martin \& Hetrick, supra note 7, at 181 (stating that lesbian, gay, and bisexual "youngsters' problems do not stem from their sexual orientation per se, but from the hatred that is dirccted toward them because of their orientation"); Savin-Williams, supra note 19, at 261.

Often, [queer] youth face an increased risk of medical and psychosocial problems, caused not by their sexual orientation, but by society's extremely negative reaction to it. Gay, lesbian, and bisexual youth face rejection, isolation, verbal harassment and physical violence at home, in school and in rehigious institutions. Responding to these pressures, many lesbian, gay and bisexual young people engage in an array of risky behaviors.

Id. (quoting CENTER FOR POPULATION OPTIONS, LESBIAN, GAY, AND BISEXUAL YOUTH 1 (1992)).

31. For example, in some studies, the students surveyed have resided only in urban areas, have consciously sought help in dealing with their sexual orientation, and were "out" to themselves and others. All of these attributes are probably unusual characteristics in queer youth. See Savin-Williams, supra note 19 , at 262 . Commentators have also criticized some surveys of queer youth because they have drawn their entire pool of respondents from groups coinposed of individuals with mental health problems and then generalized the findings to the overall population of queer youth. See, e.g., Anthony R. D'Augelli \& Scott L. Hershberger, Lesbian, Gay, and Bisexual Youth in Community Settings: Personal Challenges and Mental Health Problems, 21 AM. J. COMMUNITY PSYCHOL. 421, 424 (1993). Thus, critics charge, some suicide studies have been "negatively biased; that is, the gay and lesbian subjects were troubled youth recruited at drop-in shelters or outreach programs and therefore predisposed to a higher risk of suicide to begin with." KURT CHANDLER, PASSAGES OF PRIDE 201 (1995). 
harassment. ${ }^{32}$ Such criticism is particularly valuable in highlighting the need for more representative and inclusive surveys and investigations of queer students, and in presenting queer students with a more positive model. However, the exact percentage of students who experience the negative consequences of harassment is "almost irrelevant."33 Even though many of the existing studies have methodological problems, there is enough evidence to deduce that peer sexual orientation harassment has severe negative consequences for a significant number of gay, lesbian, and bisexual students. ${ }^{34}$

Ritch C. Savin-Williams reviewed the literature that discusses verbal and physical abuse of queer youth and the conseqnences of that harassment. ${ }^{35} \mathrm{He}$ concluded that verbal harassment and threats of physical harm to which peers and adults subject gay, lesbian, and bisexual students "are sources of great stress to [these students], are detrimental to their mental health, and often correlate with negative outcomes such as school-related problems, substance abnse, criminal activity, prostitution, running away from home, and suicide." 36 Because of methodological problems with the studies that he reviewed, ${ }^{37}$ Savin-Williams concluded that the "causal link between these stressors and outcomes has not been scientifically established." 38 However, he was able to determine that "harassment and negative ontcomes ... are clearly associated with each other."39

Because Savin-Williams reviewed literature that surveyed AfricanAmerican, Latino, and Caucasian queer youth, ${ }^{40}$ his findings are

32. See, e.g., Edwards, supra note 12, at 352. Edwards studied thirty-seven African-American gay or bisexual male adolescents. To compare and potentially contrast results with prior surveys that had obtained participants from those who attended gay, lesbian, and bisexual support groups, Edwards used only subjects who had not participated in any therapeutic or support group. Sixty-six percent of Edwards's respondents had bcen harassed by someone who suspected them to be homosexual. See id. at 343. Despite facing such adversity, the respondents did not suffer negative effects. Edwards concluded that "[t]he adolescent who identifies himself as gay can function appropriately within his heterosexual environment ... if he develops an identity that is capable of withstanding the homophobic attitudes he will experience. It is possible for a gay adolescent to develop an integrated and positive identity." Id. at 352.

33. CHANDLER, supra note 31 , at 202.

34. See id.

35. See Savin-Williams, supra note 19.

36. Id. at 267.

37. See supra note 31 . Savin-Williams identifies additional methodological problems, including the small number of subjects that coinprised the sample groups in studies, a lack of description of the measures and procedures that the studies followed, and a focus on male subjects. See Savin-Williams, supra note 19, at 262.

38. Savin-Williams, supra note 19 , at 262.

39. Id. at 267.

40. Such literature included Mary Jane Rotheram-Borus et al., Minority Youths at High Risk: Gay Males and Runaways, in ADOLESCENT STRESS 181 (Mary Ellen Colten \& Susan Gore eds., 1991), which surveyed African-American and Hispanic gay and bisexual male youths, and other 
generally applicable to queer youth of differing races. However, as Savin-Williams noted, peer harassment may cause more severe consequences for queer youth of color. In particular, these adolescents encounter the unique tasks of "developing and defining both a strong gay identity and a strong ethnic identity," facing "potential conflicts in allegiance," and experiencing "both homophobia and racism."

Truancy, dropping out, and poor academic perfornnance correlate strongly with peer sexual orientation harassment. ${ }^{42}$ In response, one Southern California school district developed a "continuation school," which is in essence a separate campus, to provide a safe educational space for students who were subject to severe harassment and/or physical assault by classmates. ${ }^{43}$ New York City's Harvey Milk School serves a similar function. ${ }^{44}$ However, these schools are unusual, and students who suffer harassment or assault may often drop out or attend school irregularly to avoid their peers. ${ }^{45}$ Other consequences of peer sexual orientation harassment include running away from home, substance abuse, ${ }^{46}$ conflict with the law, and prostitution. ${ }^{47}$

Finally, peer sexual orientation harassment correlates with suicide. ${ }^{48}$ "Studies of lesbian, gay male, and bisexual youths report suicide

studies that included representatives samples of Hispanic, African-American, and Caucasian queer youth within their subject groups.

41. Savin-Williams, supra note 19, at 267 (quoting R. C. Savin-Williams \& R. G. Rodriguez, A Developmental, Clinical Perspective on Lesbian, Gay Male, and Bisexual Youths, in 5 ADOLESCENT SEXUALITY 77, 94 (T. P. Gullotta et al. eds., 1993)).

42. See id. at 264 .

43. See Jackie Goldberg, Fighting the Battles in the Public Sector, 5 S. CAL. REV. L. \& WOMEN'S STUD. 119, 126 (1995).

44. See Kelli Kristine Armstrong, The Silent Minority Within a Minority: Focusing on the Needs of Gay Youth in Our Public Schools, 24 GOLDEN GATE U. L. REV. 67, 92 (1994).

45. See Dennis \& Harlow, supra note 17, at 446 (stating that peer sexual orientation harassment "undermine[s] the ability of gay students to learn in school and frequently cause[s] them to forfeit a high scliool education altogether"); Gibson, supra note 18, at 112-13 (asserting that for queer students, the "shame of ridicule and fear of attack makes scliool a fearful place to go resulting in frequent absences and sometimes academic failure"); Martin \& Hetrick, supra note 7, at 169, 179 (explaining that truancy and withdrawal from school activities are two ways in whicl queer students may respond to mistreatment, and noting that sclsool may become too punishing and dangerous for some students to continue to attend).

46. See Gibson, supra note 18, at 110 (stating that as a result of eertain pressures, including plrysical and verbal abuse, lesbian and gay youth are more vulnerable to substance abuse); Treadway \& Yoakam, supra note 17, at 353-54.

47. See Saviu-Williams, supra note 19, at 264-66.

48. Among the numerous studies in this area, Paul Gibson's article in the United States Department of Health and Human Services report on youth suicide, published in 1989, has received the most recognition. See Gibson, supra note 18. Gibson asserted that "gay youth are 2 to 3 times more likely to attempt suicide than other young people," and that "20-30 percent of all youth suicides may involve gay youth." Id. at 110,115 . However, as commentators have noted, Gibson arrived at these figures by comparing various studies that had already been done, sometimes using figures regarding lesbian and gay adults and generalizing to queer youth. As a result, these numbers are probably more speeulative than those found in other studies discussed lerein. For a brief discussion of 
attempts in the $20 \%$ to $40 \%$ range." 49 In comparison, studies of the general high school population report a rate of suicide attempts that range from $6 \%-13 \% .{ }^{50}$ Thus, gay, lesbian, and bisexual students are at higher risk of suicide than their heterosexual counterparts.

Among the multiple causes for the higher rate of suicide attempts, peer harassment is an important risk factor. ${ }^{51}$ In one study of gay and bisexual male youths, $39 \%$ of the youths had attempted suicide. ${ }^{52}$ Ridicule of their sexual identity was one of the stressors that increased the risk of suicide; $57 \%$ of those subjects who attempted suicide had been ridiculed while only $45 \%$ of those who had not attempted suicide had experienced ridicule. ${ }^{53}$

Another study of gay and bisexual males found that those respondents who had attempted suicide were "more likely than nonattempters to be feminine or undifferentiated, and less likely to be masculine or androgynous." 54 As a result, the study concluded that gender nonconformity was a predictor of self-harm. ${ }^{55}$ In discussing this result, the authors explained that a feminine or undifferentiated gender role im gay and bisexual male youths often exacerbates problems, because these youths may experience "an abnormal amount of depression and social conflict resulting from peer rejection, isolation, and ridicule of their feminine behavior." 56 Additionally, the study found that a common precipitant of suicide attempts was conflict with peers, with $22 \%$ of attempters reporting that their attempt(s) followed such an conflict. ${ }^{57}$ These results suggest that peer rejection and ridicule, as well as other conflicts with peers, are associated with suicide attempts in gay and bisexual male youths.

Finally, a recent study identifying negative reactions from peers as a risk factor for suicide attempts by lesbian, gay, and bisexual youth

Gibson's methodology, see D'Augelli \& Hershberger, supra note 31, at 424 . Savin-Williams discusses Gibson's report but does not appear to rely heavily on it; for example, he acknowledges the figures that Gibson presents but notes also that the "empirical documentation [in other studies] is one of accord." Savin-Williams, supra note 19, at 266.

49. Savin-Williams, supra note 19 , at 266.

50. See D'Augelli \& Hershberger, supra note 31, at 424.

51. See Savin-Williams, supra note 19 , at 267.

52. See id at 266.

53. See id.

54. Gary Remafedi et al., Risk Factors for Attempted Suicide in Gay and Bisexual Youth, 87 PEDIATRICS 869, 873 (1991).

55. The study also found that compared to nonattempters, attempters described themselves as gay or bisexual at younger ages. Additionally, attempters engaged in both heterosexual and homosexual sexual behavior at younger ages. See id. at 873-74.

56. Id. at 874 (quoting A.C. Rosen et al., Theoretical and Diagnostic Issues in Child Gender Disturbances, 13 J. SEX R OLES 89 (1977)).

57. See id, at 871 . 
concluded that there is a need for comprehensive intervention. ${ }^{58}$ This study suggested that "[1]oss of friends as a result of disclosure of sexual orientation and other negative peer reactions might become the focus of educational programs about sexual orientation offered withm school systems." $" 59$

Harassment may produce negative outcomes for a gay, lesbian, or bisexual student even if that student is not the specific target of harassment. ${ }^{60}$ If one queer student witnesses a classmate harassing another classmate due to his or her sexual orientation, she can discern the harasser's opinion about homosexuality. This may lead the student to avoid contact with peers to avoid discovery. In turn, this isolation could increase the risk of academic failure, truancy, suicide, substance abuse, and other harmful outcomes. For example, Martin and Hetrick found that each gay, lesbian, or bisexual youth who reported a suicide attempt in their study stated that a factor in their attempt was "feeling totally alone with no one to talk to." 61 They also concluded that isolation lay at the root of many educational problems, including fear of calling attention to oneself by answering $\mathrm{m}$ class or by attending physical education classes. ${ }^{62}$ Similar feelings of alienation may lead queer adolescents to curtail participation in school activities and socialization with samesex peers. ${ }^{63}$

Thus, for students who are the direct victims of harassment and their classinates who witness the abuse, harassment often produces devastating effects, including loss of life. ${ }^{64}$ The frequency and severe consequences of peer sexual orientation demand a remedy to this problem. The next Part discusses existing laws that provide students with some protection against peer sexual orientation harassment.

58. See D'Augelli \& Hershberger, supra note 31 , at $439-42,445$.

59. Id. at 445 .

60. See Gonsiorek, supra note 30 , at 473 ("Rejection by pecrs need not be experienced directly in order to be felt keenly. Many gay and lesbian youth observe the treatment of peers and clearly understand what could happen to them if they appear to be, or are known to be, different.").

61. Martin \& Hetrick, supra uote 7, at $\mathbf{1 7 2 .}$

62. See id. at 179.

63. See Deborah Zera, Coming of Age in a Heterosexist World: The Development of Gay and Lesbian Adolescents, 27 ADOLESCENCE 849, 850 (1992).

64. See Savin-Williams, supra note 19 , at 267.

The variety of problematic behaviors described in this review may very well end the lives of many bisexual, lesbian, and gay male youths. Running away from home, engaging in high-risk sexual behavior, prostituting oneself, and abusing substances all place youth at high risk for suicide or being the victim of lomicide.

Id. 
II

\section{Current Legal Remedies for SeXual Orientation DisCRIMINATION IN EDUCATION}

\section{A. The Equal Protection Clause}

"The Equal Protection Clause of the Fourteenth Amendment commands that no State shall 'deny to any person within its jurisdiction the equal protection of the laws,' which is essentially a direction that all persons similarly situated should be treated alike."65 However, only state action undertaken with a discriminatory purpose violates Equal Protection rights; action that merely disproportionately impacts one group fails to trigger Equal Protection liability. ${ }^{66}$ Furthermore, the Equal Protection Clause does not impose any affirmative duty on the state to protect the health or welfare of its people, although it does prohibit state actors from intentionally deciding not to provide protective services based on certain suspect characteristics. ${ }^{67}$ Thus, at least under the Equal Protection Clause, the state is free to refuse to protect any of its citizens without incurring liability. But if, for example, "a state or city deliberately refused to provide police protection for women, it would be violating the equal protection clause."68 For these reasons, proof of the government's motive is critical in an Equal Protection case. A plaintiff may establish an invidious intent through direct or circumstantial evidence. ${ }^{69}$ In some circumstances, a discrimmatory motive can be "inferred from the mere fact of differences in treatment."

Even when a plaimtiff demonstrates intentional discrimination, ${ }^{71}$ a defendant can still escape liability by showing that its conduct withstands a certain level of scrntiny. In the case of conduct that discriminates based on sex, the courts employ a heightened scrutiny analysis. ${ }^{72}$ For a claim of sexual orientation discrimmation, the courts utihze rational basis scrutiny. ${ }^{73}$

65. City of Clebume v. Clebume Living Ctr., Inc., 473 U.S. 432, 439 (1985).

66. See Washington v. Davis, 426 U.S. 229, 238-48 (1976).

67. See Bohen v. City of East Chicago, 799 F.2d 1180, 1189-90 (7th Ctr. 1986) (Posner, J., concurring).

68. Id at 1190 .

69. See International Bhd. of Teamsters v. United States, 431 U.S. 324, 335-36 n.15 (1977).

70. Id. at 335 n.15.

71. Throughout this Comment, I use the terms "intentional discrimination," "based on sex," and "but-for" synonymously. These terms all signify that a student is selected for harassment on the basis of that student's sex. In such a situation, "but-for" the victim's sex-i.e., if she had been of the opposite sex-she would not have been harassed.

72. See Nabozny v. Podlesny, 92 F.3d 446, 454 (7th Cir. 1996).

73. See Romer v. Evans, 116 S. Ct. 1620, 1627 (1996). 


\section{Nabozny v. Podlesny}

Jamie Nabozny's case helps to illustrate the remedies that the Equal Protection Clause provides, the Clause's limited scope, and in what respect there is a lack of protection for students subject to peer sexual orientation harassment. Nabozny reported the harassinent and physical attacks by his classmates to school officials and requested that they protect him and punish the perpetrators. ${ }^{74}$ However, school officials failed to do so. As a result, Nabozny filed a civil rights action against the school district and school officials alleging that the defendants had violated his Fourteenth Amendment right to Equal Protection. ${ }^{75}$ Because the Equal Protection Clause imposes no affirmative duty on state actors to protect students, Nabozny bore the burden of establishing that the school failed to protect him because it possessed a discriminatory purpose. ${ }^{76} \mathrm{He}$ alleged that school officials had two such discriminatory purposes: (1) they failed to protect him because of his sex, and (2) they failed to protect him because of his sexual orientation. The district court granted the defendants' motion for summary judgment, finding that Nabozny failed to produce evidence to establish that the defendants discriminated against him based on his sex or his sexual orientation. ${ }^{77}$

The Seventh Circuit Court of Appeals reversed. ${ }^{78}$ Nabozny attempted to establish that the school possessed a discriminatory motivethat they treated him differently because of his sex or his sexual orientation-by showing that the school protected female students and heterosexual students against harassment but failed to protect him. The Nabozny defendants asserted that they had anti-harassment policies, that those policies were vigorously enforced, and that they provided protection to all students. ${ }^{79}$ Nabozny did not contest the defendants' assertion that, in most cases, the defendants afforded sufficient protection. Nabozny agreed that when inale students harassed and/or battered female students, the school's response was swift and stern. ${ }^{80}$ However, Nabozny presented evidence showing that the defendants failed to provide protection in his case. ${ }^{81}$ By presenting evideuce contrasting the defendants' treatment of incidents involving heterosexual female victims with his case, Nabozny attempted to prove that either a discriminatory purpose toward males or toward homosexuals motivated the defendants. With regard to his sexual orientation claim, Nabozny introduced

\footnotetext{
74. See supra text accompanying notes $2-5$.

75. See Nabozny, 92 F.3d at 449 .

76. See id. at 453-54.

77. See id. at 449,453 .

78. See id.

79. See id. at 455 .

80. See id. at 454 .

81. See id.
} 
additional evidence that the defendants treated him differently because he was gay, including statements by the defendants that Nabozny should expect harassment because of his sexual orientation. ${ }^{82}$

In reversing the grant of summary judgment to the defendants on the sex discrimination claim, the court of appeals found that the record provided enough evidence of intentional sex discrimination to withstand a motion for summary judgment. ${ }^{83}$ Additionally, the defendants failed to put forth any important governmental objective to justify their intentional sex discrimination; thus, an inquiry into whether their discrimination could withstand heightened scrutiny was unnecessary. ${ }^{84}$

On the sexual orientation claim, the court held that Nabozny presented sufficient evidence to show that he received discriminatory treatment and that the treatment was motivated by the defendants' disapproval of his sexual orientation. ${ }^{85}$ Moreover, the court stated that it was "unable to garner any rational basis for permitting one student to assault another based on the victim's sexual orientation" and noted that the defendants did not offer one. ${ }^{86}$ Shortly after the Seventh Circuit's ruling, the defendants reportedly settled with Nabozny for $\$ 900,000 .^{87}$

Nabozny is an extremely important and helpful precedent for students who suffer sexual and/or sexnal orientation harassment. The Nabozny court plainly held that different responses to students' complaints of harassment may amount to intentional sex discrimination that violates the Equal Protection Clause. This constitutional protection is particularly important because it is not yet firmly established whether student-to-student sexual harassment is actionable under Title IX, the federal statute that bars sex-based discrimination in education. ${ }^{88}$

Moreover, Nabozny severely limits a school's ability to discriminate based on sexual orientation. Notably, the court recognized that smce 1988 , it has been well established that discrimination based on sexual orientation violates the Equal Protection Clause absent a rational basis. ${ }^{89}$ Of course, rational basis review is usually an easy standard for defendants to ineet. ${ }^{90}$ However, the Nabozny court stated that it could not conceive of any reason to allow one student to assault another because of the student's sexual orientation. Thus, future defendants may have

\footnotetext{
82. See id. at 451 .

83. See id. at 455 .

84. See id. at 456 n.8.

85. See id. at 457 .

86. Id. at 458 .

87. See Gay Man Wins $\$ 900,000$ in School-District Case, WALL ST. J., Nov. 21, 1996, at A6.

88. See infra text accompanying notes $120-125$.

89. See Nabozny, 92 F.3d at 458.

90. See LAURENCE H. TRIBE, AMERICAN CONSTITUTIONAL LAW 343, 1443 (2d ed. 1988) (stating that the rational relationship requirement imposes on Congress only "relatively toothless limits" and is "largely equivalent to a strong presumption of constitutionality").
} 
greater difficulty convincing courts that there is a rational basis for failing to take action against student-to-student sexual orientation harassment.

\section{Gaps in Constitutional Protection}

Although there are many positive aspects of the Nabozny decision, the law that it establishes is limited. To demonstrate a violation of Equal Protection rights, a plaintiff must show intentional discrimination; mere negligence will not suffice. Under the Equal Protection Clause, it is a sufficient defense that a school failed to act out of mistake-for example, a school might argue that a case "slipped through the cracks" and, despite the school's good intentions, no administrator dealt with the harassment. A law providing more coinplete protection would not make a student's ability to obtain relief from peer sexual orientation harassment contingent on the school possessing a bad notive.

Another problem in regard to the Equal Protection Clause is that proving intentional discrimination often presents difficult evidentiary hurdles, which are magnified in the area of student-to-student harassment. For example, it is unclear whether a student's discriminatory intent is simply imputed to school officials once the school officials becoine aware of the harassment and fail to respond adequately, or if the plaintiff must produce additional evidence concerning school officials' state of mind and decision-making criteria. ${ }^{91}$

Additionally, soine schools may attempt to argue that there is a rational basis for discriminating against students based on their sexual orientation. Although Nabozny rejected this defense, other courts are still free to accept it. ${ }^{92}$

\section{B. State Statutes Addressing Sexual Orientation Discrimination in Schools}

Massachusetts, Vermont, Wisconsin, and the District of Columbia have statutes that explicitly address sexual orientation discrimination in schools. ${ }^{93}$ Like the Equal Protection Clause, these statutory provisions

91. Cf. infra notes 120-125 and accompanying text (discussing statutory student-to-student claims).

92. See TRIBE, supra note 90 , at 1443.

93. See D.C. CODE ANN. $\$ 1-2520$ (1997) ("It is an unlawful discriminatory practice ... for an educational institution ... [t]o deny, restrict, or to abridge or condition the use of, or access to, any of its facilities and services to any person otherwise qualified ... for a discriminatory reason, based upon the ... sexual orientation ... of any individual . . . "); MASS. GEN. LAwS ANN. ch. 76, § 5 (West 1996) ("No person shall be excluded from or discriminated against in admission to a public school of any town, or in obtaining the advantages, privileges and courses of study of such public school on account of . . . sexual orientation."); VT. STAT. ANN. tit. 16, \& 11(a)(26) (1997) (requiring school boards to adopt policies that prohibit harassinent perpetrated by either students or staff based on a student's sexual orientation); WIS.STAT. ANN. $\$ 118.13(1)$ (West 1991) ("No person may be 
are helpful but limited in scope. They share with the Equal Protection Clause the requirement that the harasser and/or the school acted or failed to act "because of" the victim's sexual orientation. As compared with existing state statutory provisions, a more expansive law, such as this Comment's proposed statute, would possess no such limitation and thus furnish more comprehensive protection. ${ }^{94}$

These state statutes apply to what courts commonly term "sexual orientation" discrimination. Likewise, the Equal Protection Clause, as Nabozny demonstrates, forbids sexual orientation discrimination in some circumstances. In contrast, other laws explicitly apply only to "sex" discrimination. In the following Part, I discuss the most prominent federal sex discrimination statutes: Title $\mathrm{IX}^{95}$ and Title VII. ${ }^{96}$ At first glance, they may seem irrelevant to "sexual orientation" harassment. However, because "sexual orientation" discrimination is in fact sex discrimmation, courts should interpret these laws to prohibit "sexual orientation" discrimination, including sexual orientation harassment.

\section{III}

\section{SEX Discrimination}

Although most courts are reluctant to interpret laws that prohibit sex discrimination as prohibiting sexual orientation discrimination, ${ }^{97}$ one court recently adopted such an interpretation of sex discrimination law. ${ }^{98}$ As a result, queer students may be able to use existing sex discrimination laws to secure relief against sexual orientation harassment.

denied admission to any public scliool or be denied participation in, be denied the benefits of or be discriminated against in any curricular, extracurricular, pupil services, recreational or other program or activity because of the person's ... sexual orientation .....").

94. Vermont's statute may offer protection broader than that provided by the Equal Protection Clause and other states' statutes. It provides that:

[s] exual harassment is also a form of unlawful harassment and means unwelcome sexual advances, requests for sexual favors and other verbal or physical conduct of a sexual nature when .... [t] the conduct has the purpose or effect of substantially interfering with a student's educational performance or creating an intimidating, hostile or offensive educational environment.

VT.STAT. ANN. tit. 16, §11(a)(26) (1997). On its face, this provision, like the Comment's proposed statute, contains no requirement that the sexual harassment at issue be motivated by the student's sex or sexual orientation. Instead, it outlaws "verbal or physical conduct of a sexual nature" when that conduct creates a "hostile educational environment." However, because the statute refers to "verbal or physical conduct of a sexual nature," and not, for example, "words or conduct of a sexual nature or that refer to sexual orientation," it is unclear whether the Vermont law applies if one student calls another a "fag." For this reason, section l(a)(ii) of the proposed statute, which clearly prohibits harassment that refers to sexual orientation, likely provides more reliable protection for students.

95. 20 U.S.C. $\$ \S 1681-1688$ (1995).

96. 42 U.S.C. $\$ \$ 2000 \mathrm{e}$ to $2000 \mathrm{e}-17$ (1995).

97. See, e.g., DeSantis v. Pacific Tel. \& Tel. Co., 608 F.2d 327, 331 (9th Cir. 1979).

98. See Baehr v. Lewin, 852 P.2d 44 (Haw. 1993). 


\section{A. Title IX}

Title IX provides, in relevant part, that "[n]o person in the United States shall, on the basis of sex, be excluded from participation in, be denied the benefits of, or be subjected to discrimination under any education program or activity receiving Federal fniancial assistance." tle IX thus prohibits sex-based discrimination in education.

Courts frequently look to Title VII case law for guidance when interpreting Title IX. ${ }^{100}$ Title VII is a federal statute that applies to sex discrimination in eniployment. A student may sue a school based on a violation of Title IX, but cannot do the same under Title VII because students are not eniployees. Likewise, an entployee niay not bring a Title IX action. Title VII, as conipared with Title IX, is older, has a more extensive legislative history, and carries with it a much greater volume of case law history. How fully Title VII standards should be applied in Title IX cases is the subject of judicial debate. Nonetheless, because courts often depend on analogous Title VII cases when considering Title IX, this Part provides background on Title VII before directly discussing Title IX.

\section{Title VII Background}

Title VII protects enployees from sex-based discrimination by their employers. ${ }^{101}$ Three terms are comnionly used to describe the various types of causes of action that are available under Title VII: disparate treatment, disparate impact, and sexual harassnient claims. Sexual harassment claims are the most relevant to students who attenipt to secure relief under Title IX for peer sexual orientation harassnient. Disparate treatnient is also iniportant because courts rely on disparate treatment analysis when deciding sexual harassment claims. Finally, disparate impact is pertinent to this Cominent because these claims, like the statute that this Cominent proposes, contain no intent requirement.

By aiming to ensure equal treatnient of all employees and applicants, "disparate treatment" liability shares much in conımon with the Equal Protection Clause. Disparate treatment is used in situations in which an employer treats male and feniale eniployees differently

99. 20 U.S.C. § 1681(a) (1995) (emphasis added).

100. See, e.g., Murray v. New York Univ. College of Dentistry, 57 F.3d 243, 248 (2d Cir. 1995); Preston v. Virginia ex rel. New River Community College, 31 F.3d 203, 206 (4th Cir. 1994); Lipsett v. University of Puerto Rico, 864 F.2d 881, 896-97 (1st Cir. 1988).

101. Title VII makes it "an unlawful employment practice for an employer ... to discriminate against any individual with respect to his compensation, terms, conditions, or privileges of employment, because of such individual's ... sex." 42 U.S.C. § 2000e-2(a) (1995). It is also unlawful for an einployer "to limit, segregate, or classify his employees ... in any way which would deprive or tend to deprive any individual of employment opportunities or otherwise adversely affect his status as an employee, because of such individual's ... sex." Id. § 2000e-2(a)(2). 
because of their sex. Under this theory, liability attaches only if the employer's motivation for the differential treatment is the employee's sex. ${ }^{102}$ Thus, in a disparate treatment case, proof of the employer's discriminatory motive is the critical element of a plaintiff's case. ${ }^{103}$

In contrast, Title VII's "disparate impact" model prohibits behavior that acts as a barrier to equal opportunity regardless of the behavioral motivation. ${ }^{104}$ It is unnecessary under the "disparate impact" theory to show that an employer based its employment decisions on the sex of its employees. ${ }^{105}$ Instead, disparate impact liability may attach if an employment practice, such as requiring that employees have a college degree, excludes a disproportionate number of men or women from competing for the job, regardless of the employer's intent in carrying out the practice at issue. ${ }^{106}$

"Sexual harassment" claims form the third subset of Title VII litigation. Courts recognize two types of sexual harassment cases: (1) quid pro quo sexual harassment, and (2) hostile work environment sexual harassment. ${ }^{107} \mathrm{~A}$ quid pro quo claim is one in which the plaintiff alleges that her supervisor demanded sexual favors in exchange for either a grant of a positive employment action or a promise not to carry out a threatened adverse employment action. ${ }^{108}$ Under the hostile work environment theory, "a plaintiff may establish a violation of Title VII by proving that discrimination based on sex has created a hostile or abusive work environment." 109 In most jurisdictions, this cause of action requires the plaintiff to show that she was subject to unwelcome harassment because of her sex, that the harassment was sufficiently severe or pervasive to create an abusive work environment, and that there is a basis for employer liability. ${ }^{110}$ The first prong requires that the harasser have chosen his victim "because of" her sex. Thus, in analyzing whether the

102. See International Bhd. of Teamsters v. United States, 431 U.S. 324, 335-36 n.15 (1977).

103. As with Equal Protection claims, a plaintiff can establisl proof of motivation with any evidence the plaintiff can muster, including circumstantial evidence. See supra text accoinpanying notes 69-70.

104. See Teamsters, 431 U.S. at 335-36 n.15.

105. See id. at $336 \mathrm{n} .15$ ("Proof of discriminatory motive ... is not required under a disparateimpact theory.").

106. See 42 U.S.C. $\$ 2000 \mathrm{e}-2(\mathrm{k})$ (1995) ("An unlawful employment practice based on disparate impact is establislled ... if . . . a complaining party demonstrates that [an employer] uses a particular employment practice that causes a disparate impact on the basis of . . . sex . . . ."); Griggs v. Duke Power Co., 401 U.S. 424, 429-32 (1971). However, an employer may still avoid liability for an employment practice that lias a disparate impact if it can show that it is "job related for the position in question and consistent with business necessity." 42 U.S.C. $§ 2000 \mathrm{e}-2(\mathrm{k})(1)(\mathrm{A})(\mathrm{i})$ (1995).

107. See Dale Carpenter, Same-Sex Sexual Harassment Under Title VII, 37 S. TEX. L. REV. 699, 703 (1996).

108. See Meritor Sav. Bank v. Vinson, 477 U.S. 57, 65 (1986).

109. Id. at 66 .

110. See Doe v. Petaluma City Sch. Dist., 949 F. Supp. 1415, 1423 (N.D. Cal. 1996); see also Carpenter, supra note 107, at 704-05. 
first prong is met, a disparate treatment-type analysis is necessary to determine whether the sex of the victim motivated the harasser. If it did not, then the plaintiff's claim fails. With respect to the third prong, the Supreme Court has instructed lower courts to look to agency principles for guidance $\mathrm{m}$ developing rules on employer liability. ${ }^{111}$ Pursuant to this instruction, the Ninth Circuit held that an employer is liable for failing to remedy or prevent a hostile work environment of which it knew, or in the exercise of reasonable care, should have known existed. ${ }^{112}$ Other jurisdictions have also developed rules on employer liability. ${ }^{113}$

\section{Interpretation of Title IX}

Enacted in 1972, Title IX has slowly and somewhat haltingly provided increasing protection to students who experience sex discrimination. In 1979, the Supreme Court held that Title IX provides a private right of action. ${ }^{114}$ In response to subsequent Court decisions that narrowed the application of Title $\mathrm{IX}^{115}$ Congress enacted additional legislation making Title IX applicable to an entire educational institution if any part of it receives federal aid. ${ }^{116}$

Most recently, in Franklin v. Gwinnet County Public Schools, ${ }^{117}$ the Court held that a Title IX student plaintiff may recover inonetary damages against a school district in some situations. ${ }^{118}$ The Franklin plaintiff claimed that a teacher sexually harassed her and that the school system knew of the harassment but took no steps to stop it. In a now widely debated passage, the Court held that:

Title IX placed on the [school system] the duty not to discriminate on the basis of sex, and "when a supervisor sexually harasses a subordinate because of the subordinate's sex, that supervisor 'discriminate[s]' on the basis of sex." We believe the same rule should apply when a teacher sexually harasses and abuses a student. Congress surely did not intend for federal

111. See Meritor Sav. Bank, 477 U.S. at 72.

112. See EEOC v. Hacienda Hotel, 881 F.2d 1504, 1515-16 (9th Cir. 1989).

113. See Carpenter, supra note 107, at 704-05.

114. See Cannon v. University of Chicago, 441 U.S. 677, 709, 717 (1979).

115. See Atascadero State Hosp. v. Scanlon, 473 U.S. 234, $246-47$ (1985) (holding that mere acceptance of federal funds does not automatically waive state's Eleventh Amendment immunity); Grove City College v. Bell, 465 U.S. 555, 570-74 (1984) (narrowly defiming what constitutes a "program"); North Haven Bd. of Educ. v. Bell, 456 U.S. 512, 535-40 (1982) (holding that only specific program receiving federal money must adhere to Title IX mandates).

116. See 20 U.S.C. \& 1687 (1995).

117. 503 U.S. 60 (1992).

118. See id. at 74-75. 
moneys to be expended to support the intentional actions it sought by statute to proscribe. ${ }^{119}$

This passage clearly allows plaintiffs to recover monetary damages when a school "intentionally discriminates" against a student in a situation involving teacher-to-student sexual harassinent. However, the Court failed to define what would constitute "intentional discrimination" in other situations, such as student-to-student sexual harassment. In addition, by relying on Meritor, a Title VII hostile work environment case, the Court left unclear the degree to which lower courts should incorporate Title VII substantive law into Title IX.

This uncertainty has contributed to widespread confusion among lower courts in the area of student-to-student sexual harassment claims under Title IX. ${ }^{120}$ At one extreme, the Fifth Circuit inposes Title IX liability on a school district only when that school district itself directly discriminates based on sex. ${ }^{121}$ In explaining what suffices to prove discrimination, the Fifth Circuit appeared to place an almost insurmountable evidentiary burden on plaintiffs who atteinpt to prove intentional discrimination, holding that:

[in] the case of peer sexual harassment, a plaintiff must demonstrate that the school district responded to sexual harassment claims differently based on sex. Thus, a school district might violate Title IX if it treated sexual harassment of boys more seriously than sexual harassment of girls, or even if it turned a blind eye toward sexual harassment of girls while addressing assaults that harmed boys. ${ }^{122}$

At the other extreme is Doe v. Petaluma City School District. ${ }^{123}$ In Doe, the Northern District of California court held that Title VII standards of liability for hostile environment sexual harassment apply directly to student-to-student sexual harassment claims under Title IX.124 The court concluded that money damages are available in Title IX student-to-student sexual harassment claims because sexual harassment involves "intentional" discrimination. In reaching this conclusion, the court focused on two requirements. The first is that a student harasser have chosen his victim based on the victim's sex. The second is that the

119. Id. (quoting Meritor Sav. Bank v. Vinson, 477 U.S. 57, 64 (1986)).

120. Aside from Franklin, confusion exists in regard to how fully to apply Title V1I standards in Title $1 \mathrm{X}$ cases because the two statutes are not identically worded, and because the two statutes were enacted under different Congressional powers. Title IX was enacted under the Spending Clause, and such legislation allows for monetary damages only in cases of "intentional" discrimination. See Franklin, 503 U.S. at 74-75. Title VII is not encumbered with such a limitation.

121. See Rowinsky v. Bryan Indep. Sch. Dist., 80 F.3d 1006, 1016 (5th Cir.), cert. denied, 117 S. Ct. 165 (1996).

122. Id.

123. 949 F. Supp. 1415 (N.D. Cal. 1996).

124. See id. at 1417-18. 
school "knew, or in the exercise of reasonable case [sic] should have known, of the existence of the hostile environment."125 The court reasoned that by failing to respond adequately when it knows or should know of a hostile environment, the school implicitly condones the harasser's intentional disparate treatment.

Despite the widespread confusion in the lower courts, to date, the Supreine Court has not addressed whether student-to-student sexual harassment is actionable under Title IX. However, assuming that the Supreme Court would find that student-to-student sexual harassment is actionable under Title IX and that monetary damages are recoverable in at least some circumstances, the next question is whether Title IX offers any relief to gay, lesbian, and bisexual students who are harassed by classmates based on sexual orientation.

In answering this question, I argue that sexual orientation harassment constitutes sex discrimination. For this reason, if peer sexual harassment is actionable under Title IX-i.e., if courts find that a school's failure to remedy peer sexual harassinent is discrimination "based on sex" within the meaning of Title IX-courts should also interpret Title IX's prohibition of discrimination based on sex as encompassing peer sexual orientation harassment. ${ }^{126}$ However, I also acknowledge that courts are unlikely to do so. Throughout this analysis, I also emphasize why statutes that rely on the intent of harassers or institutions to establish liability are insufficient to protect students.

\section{B. The "Based on Sex" Requirement}

Numerous cominentators have cogently explained why sexual orientation discrimination is, in fact, sex discrimination. ${ }^{127} \mathrm{I}$ will first

125. Id. at 1423 .

126. Even if the Supreme Court eventually finds that student-to-student sexual harassment is not actionable under Title IX, there are other laws that prohibit sex-based discrimination in education. See, e.g., ALASKA STAT. $\$ 14.18 .010$ (Michie 1997) ("A person in the state may not on the basis of sex be excluded from participation in, be denied the benefits of, or be subjected to discrimination under any education program or activity receiving federal or state financial assistance."); CAL. EDUC. CODE § 220 (West 1998) ("No person shall be subjected to discrimination on the basis of sex in any program or activity conducted by an educational institution which receives or benefits from state financial assistance or enrolls students who receive state student financial aid."). Even if Title IX were unavailable to remedy student-to-student sexual harassment, gay, lesbian, and bisexual students could still attempt to argue that these other sex discrimination statutes prohibit peer sexual orientation harassment.

127. See, e.g., Mary Anne C. Case, Disaggregating Gender From Sex and Sexual Orientation: The Effeminate Man in the Law and Feminist Jurisprudence, 105 YALE LJ. 1 (1995); Amelia A. Craig, Musing About Discrimination Based on Sex and Sexual Orientation as "Gender Role" Discrimination, 5 S. CAL. REV. L. \& WOMEN'S STUD. 105 (1995); Marc A. Fajer, Can Two Real Men Eat Quiche Together? Storytelling, Gender-Role Stereotypes, and Legal Protection for Lesbians and Gay Men, 46 U. MIAMI L. REV. 511 (1992); Andrew Koppelman, Why Discrimination Against Lesbians and Gay Men is Sex Discrimination, 69 N.Y.U. L. REV. 197 (1994); Sylvia A. Law, Homosexuality and the Social Meaning of Gender, 1988 WIS. L. REV. 187; Samuel A. Marcosson, 
summarize two main lines of thought on the issue, including discussions of various courts' reactions to (and mostly rejections of) the argument that sexual orientation discrimination constitutes sex discrimination. I conclude that most of the courts that reject the argument that sexual orientation discrimination is sex discrimination attempt to justify their decisions by pointing to the harasser's notivation in choosing a particular victim or by relying on the employer's motivation for failing to stop the harassment. As my discussion below makes clear, this is an illegitimate basis for rejecting plaintiffs' claims.

One main purpose of my analysis is to highlight the ways $m$ which courts are free to manipulate how they investigate and frame the intent or motivation of harassers, employers, or school districts. Through such manipulation, courts are able to turn an actionable sex discrimination claim into a dismissable sexual orientation discrimination claim.

\section{The "Identically Situated" Argument}

As Francisco Valdes explains, "a person's sexual orientation in fact is deemed based on her or his sex (im conjunction with the sex of her or his beloveds)." 128 That is, a lesbian becomes the object of sexual orientation harassment because she is a woman in a relationship with a woman; a man in a relationship with a woman would not be subject to the sanie harassment. In discriminating against gay or lesbian adolescents, schools necessarily refer to those adolescents' sex in their decision-making process. Thus, discrimination against gay, lesbian, and bisexual students is inescapably sex discrimination. Put another way, sexual orientation discrimination is sex discrimination because the perpetrator is treating identically situated individuals differently, solely based on the sex of the individuals and their beloveds.

One possible counter-argument is that the employer is not discriminating based on sex; instead, he treats men and women exactly alike by firing either a man or a woman who has sex with someone of that individual's same sex. ${ }^{129}$ However, in Loving v. Virginia, ${ }^{130}$ the Supreme Court rejected an almost identical argument. In that case, the

Harassment on the Basis of Sexual Orientation: A Claim of Sex Discrimination Under Title VII, 81 GEO. LJ. 1 (1992); Francisco Valdes, Queers, Sissies, Dykes, and Tomboys: Deconstructing the Conflation of "Sex," "Gender," and "Sexual Orientation" in Euro-American Law and Society, 83 CALIF. L. REV. 1 (1995); I. Bennett Capers, Note, Sex(ual Orientation) and Title VII, 91 ColUM. L REV. II58 (1991).

128. Valdes, supra note 127, at 26.

I29. See DeSantis v. Pacific Tel. \& Tel. Co., 608 F.2d 327, 331 (9th Cir. 1979) ("[W]hether dealing with men or women the employer is using the same criterion: it will not hire or promote a person who prefers sexual partners of the same sex. Thus this pohicy does not involve different decisional criteria for the sexes.").

130. 388 U.S. 1 (1967). 
Court struck down a Virginia statute outlawing interracial marriages. ${ }^{131}$ Virginia argued that, because it applied the statute to people of all races who violated the statute, the statute was constitutional. The Court rejected this contention, stating that "[t]here can be no doubt that restricting the freedom to marry solely because of racial classifications violates the central ineaning of the Equal Protection Clause."132 Thus, the Court found that using racial classifications to prohibit marriage between persons of different races constituted intentional race discrimination; Virginia's equal application of this discriminatory law could not save the statute. The Hawaii Supreme Court adopted similar reasoning in Baehr v. Lewin, ${ }^{133}$ in which a plurality held that a state statute denying recognition to same-sex marriages "regulates access to the marital status and its concomitant rights and benefits on the basis of the applicants' sex. As such, [it] establishes a sex-based classification."134

The Baehr court, however, stands virtually alone in its reasoning in the sexual orientation context. Other courts faced with arguinents similar to those raised here have almost always dismissed such contentions. In one Title VII case, DeSantis v. Pacific Telephone and Telegraph $\mathrm{Co}^{1},{ }^{135}$ the plaintiffs argued that in discriminating based on the plaintiffs' homosexuality, the defendants used different employment criteria for men and woinen in violation of Title VII's ban on sex discrimination. ${ }^{136}$ That is, the employers tolerated women who had male sexual partners but not men in the saine situation; nor would the employer hire or retain women who had female sexual partners, while the employer allowed the saine of inen. ${ }^{137}$

In rejecting this contention, the DeSantis court employed reasoning already rejected by the Supreine Court in Loving, explaining that "whether dealing with men or women the employer is using the same criterion: it will not hire or promote a person who prefers sexual partners of the same sex. Thus this policy does not involve different decisional criteria for the sexes." 138 In reaching this conclusion, the DeSantis court ignored the employer's use of sex-based classifications

131. See id. at 2.

132. Id. at 12.

133. 852 P.2d 44 (Haw. 1993).

134. Id. at 64 (citation omitted). The court further held that sex-based classifications are subjeet to strict scrutiny under the Hawaii Constitution. Finally, the court remanded for determination of whether the statute furthered coinpelhing state interests and was narrowly drawn to avoid unnecessary abridgments of constitutional rights. See id. at 68 . The plurality opinion subsequently became a majority opinion when the court issued a clarification, joined by a majority of the reconstituted court, and ordered that on remand the trial be conducted consistently with the plurality opinion. See Koppelman, supra note 127, at 205.

135. 608 F.2d 327 (9th Cir. 1979).

136. See id. at 331.

137. See id. at 331.

138. Id. 
that paralleled the racial classifications that Loving had condemned. In Loving, Virginia attempted to ban marriages by looking to the races of those wishing to inarry, and in DeSantis, the employer condemned relationships by referring to the sexes of the people in the relationship. In contrast with the result in DeSantis, even-handed application of the law that used racial classification was insufficient to make the statute at issue in Loving constitutional. Through reasoning inconsistent with Loving, the DeSantis court recharacterized sex discrimination as a claim of discrimination based on "sexual orientation" by maintaining that the "intent" of the employer was to differentiate based on sexual orientation and not sex.

\section{The "Sex Stereotype" Argument}

The "sex stereotype" argument posits that by perpetuating the gender stereotype that inen and women should only maintain a sexual attraction to members of the opposite sex, discrimination against gay men and lesbians is sex discrimination. ${ }^{139}$ The Supreme Court established that "sex stereotyping" may anount to intentional sex discrimination in Price Waterhouse v. Hopkins. ${ }^{140}$ In that case, Price Waterhouse refused to promote Ann Hopkins to partnership. She brought a Title VII disparate treatment claim and produced evidence that some of the partners reacted negatively to her personality, particularly her aggressiveness, because she was a woman. For example, one partner remarked that Hopkins "overcompensated for being a woman."141 In response to the criticism, one of Hopkins' supporters "explained that Hopkins 'ha[d] matured from a tough-talking somewhat masculine hard-nosed [manager] to an authoritative, formidable, but much more appealing lady [partner] candidate." "142 In advising her how to improve her chances for partnership, one partner suggested that she "walk more femininely, talk more femininely, dress more femininely, wear make-up, have her hair styled, and wear jewelry."143

The Supreme Court held that these remarks constituted "sex stereotyping," recognizing that the Price Waterhouse partners reacted not to Hopkins' aggressiveness per se, but rather to the fact that she was a woman who possessed an aggressive personality. ${ }^{144}$ The Court ruled that employmeut decisions based on stereotypes violate Title VII's prohibition of sex discrimination. ${ }^{145}$ In particular, the Court explained that

\footnotetext{
139. See Koppelman, supra note 127, at 218-19.

140. 490 U.S. 228, 250-51 (1989).

141. Id. at 235.

142. Id. (first alteration in original).

143. Id.

144. See id. at 250 .

145. See id.
} 
"an employer who acts on the basis of a belief that a woman cannot be aggressive, or that she must not be, has acted on the basis of gender."146

In United States v. Virginia, ${ }^{147}$ the Court, in the Equal Protection context, reaffirmed that treating inen and women differently based on preconceived notions of supposed differences between men and women constitutes sex discrimination. ${ }^{148}$ In that case, the Court rejected the defendant's argument that its refusal to admit women to the Virginia Military Institute was justified because of alleged differences in the way that men and woinen respond to a military-style education. ${ }^{149}$ The Court explained that "generalizations about 'the way women are,' estimates of what is appropriate for most woinen, no longer justify denying opportunity to women whose talent and capacity place them outside the average description." 150

Using Price Waterhouse and United States v. Virginia, queer employees and students can attempt to persuade courts that the notion that woinen must only have sexual relationships with men is a sex stereotype. Thus, if Price Waterhouse had rejected Hopkins for partnership because she had a sexual relationship with another woman, she might have argued that the partners' reasoning that it is improper for woinen to have sexual relationships with women perpetuates just as strong a stereotype as the expectation that women should wear make-up and walk in a certain way. Both situations rely on stereotypes of what is appropriate behavior for women.

Although such an argument is analytically sound, in the few cases in which plaintiffs have tried to convince courts of its validity, they have failed to do so. In Dillon v. Frank, ${ }^{151}$ the plaintiff alleged that his coworker harassed him, including calling him a "fag", saying that he "sucks dicks", and physically assaulting him. ${ }^{152}$ In arguing that he stated a claim under Title VII for sex discrimination, the plaintiff explicitly relied on Price Waterhouse. ${ }^{153}$ However, one judge found that there was "no specific evidence of 'sex stereotyped remarks" in the record. ${ }^{154}$ The judge elaborated that "there is no evidence ... that [the plaintiff's] co-workers justified their outrageous behavior based on, or accompanied it with remarks indicating, a belief that his practices would be acceptable in a feinale but unacceptable in a male." 155 As Samuel

146. Id.

147. 116 S. Ct. 2264 (1996).

148. See id. at 2279-80, 2283-84.

149. See id. at 2283-84.

150. Id. at 2284 .

151. No. 90-2290, 1992 WL 5436 (6th Cir. Jan. 15, 1992).

152. Id at *1.

153. See id. at $* 5$.

154. Id. at *9.

155. Id. 
Marcosson points out, however, this reasoning is absurd; the very basis of anti-gay sentiment is that although it is acceptable for a woman to have sex with a man, it is repulsive if a man does so. ${ }^{156}$

Assuming that sexual harassment is "intentional" sex discrimination, and thus student plaintiffs can recover money damages for studentto-student sexual harassment under Title IX, student plaintiffs should also be able to recover for harassment that is based on sexual orientation. This is so because, as the foregoing discussion demonstrates, discrimination based on sexual orientation is inherently based on sex..$^{157}$

Although a proper interpretation of sex discrimination laws recognizes that sexual orientation discrimination is sex discrimination, courts have largely been unwilling to adopt this analysis. Also, even if courts were to adopt this interpretation, the scope of laws that outlaw only intentional discrimination is limited. For these reasons, existing laws, including the Equal Protection Clause and Title IX, offer incomplete protection. The next Part proposes a statute that comprehensively addresses and is designed to remedy the negative effects that student-tostudent sexual harassment causes.

\section{IV}

\section{The Proposed Statute}

\section{A. Text of Proposed Statute}

(1) If any school district knows or reasonably should know that any student is harassing or physically abusing another student, it shall be unlawful for that school to fail to take reasonable steps to remedy the harassment or physical abuse when either of the following subsections ((a) or (b)) applies:

(a) The harassment or physical abuse interferes with a student's education or otherwise creates a hostile educational environment, and the harassment or physical abuse consists of either: (i) words or conduct of a sexual nature, or (ii) words or conduct that refer to sexual orientation. Illustrative examples of types of conduct that may constitute harassment imclude name-calling, references to sexual activity or practices, "joke"-telling, and physical assault. Neither the student harasser's nor the school district's motivation im acting or failing to act is relevant for purposes of liability under this subsection.

(b) The harassment or physical abuse, although not referring to sexual orientation and not of a sexual nature, is motivated by the student victim's sex, and interferes with a student's education, or

156. See Marcosson, supra note 127 , at 26.

157. See supra text accompanying notes 127-156. 
otherwise creates a hostile educational environment. Harassment or physical abuse based on sexual orientation is undertaken on the basis of sex.

(2) To facilitate the implementation of these sections, every school district shall provide appropriate training to each teacher, counselor, athletic coach, or other student advisor whom it employs or from whom it accepts volunteer services.

(3) These sections are enforceable through a private right of action in which a student may seek money damages. ${ }^{158}$

\section{B. Overview of Proposed Statute}

Under section 1(a) of the proposed statute, actionable harassment includes any conduct or words that are of a sexual nature or that refer to sexual orientation, and that interfere with a student's education or otherwise create a hostile educational environment, regardless of the motivation behind the harassment or the school's failure to remedy it. ${ }^{159}$

Section 1(b) inposes a duty on school districts to remedy a student's discriminatory conduct. The section is meant to extend the statute's reach to harassment based on the target student's sex, whether or not the harassing student's conduct or words are of a sexual nature or refer to sexual orientation. ${ }^{160}$

The statute also states that "[h]arassment or physical abuse based on sexual orientation is undertaken on the basis of sex." This wording helps to correct current erroneous judicial constructions of sex discrimination laws that fail to recognize that sexual orientation discrimination is sex discrimination. By prohibiting harassment based on sex and by stating that harassment based on sexual orientation is undertaken

158.Either state legislatures or the United States Congress could adopt this statute. If a state adopted the statute, it would provide remedies to students independently of any federal statutes or constitional provisions and would not transform the way that federal laws are interpreted; it would merely exist alongside them as another legal option for students to pursue. If the federal government were to adopt the statute it could do so by amending the existing statute that addresses discrimination in schools to make the scope of the existing statute broader, or it could adopt the statute to stand on its own and to provide relief imdependent from other federal laws.

159. The Supreme Court has established standards for applying the First Amendment in the school setting. See Bethel Sch. Dist. No. 403 v. Fraser, 478 U.S. 675, 677-78, 685-86 (1986) (holding that school did not violate the First Amendment by suspending student who delivered speech containing graphic sexual metaphor because the school discipline was unrelated to any political viewpoint, and the speech undermined the school's basic educational mission); Tinker v. Des Moines Indep. Community Sch. Dist., 393 U.S. 503, 513 (1969) (explaining that student speech, "in class or out of it, which for any reason ... materially disrupts classwork or involves substantial disorder or invasion of the rights of others is . . not immunized by the constitutional guarantee of freedom of speech"). These standards would apply to the proposed statute.

160. Cf. Carrie N. Baker, Comment, Proposed Title IX Guidelines on Sex-Based Harassment of Students, 43 EMORY L.J. 271, 274, 297 (suggesting Title IX guidelines that "cover both sexual and gender-based nonsexual harassment"). 
on the basis of sex, section 1(b) eliminates the court's discretion to adopt narrow definitions of sex discrimination.

To maximize the effectiveness of the statute, section 2 recognizes that teachers must know how to deal with harassinent and be able to do so without negative repercussions to their own careers. In one study, the author found that "professionals benefited from specific training ou adolescent homosexuality in the context of HIV prevention."161 Likewise, teachers and other school staff would likely benefit from harassment-related training. Additionally, since discrimination against gay and lesbian teachers is still legal in most states, this legislation addresses teacher concerns about the ramifications of taking disciplinary action against anti-gay peer harassment. If remedial action is not required, teachers who take disciplinary measures run the risk of speculation by the school that they are gay, thereby making the teachers vulnerable to discrimination. Similarly, if training were only voluntary, those teachers who attend might subject themselves to potential discriminatory acts based on the perception, real or imagined, that they are gay. ${ }^{162}$

Section 3 provides for a private right of action through which students may seek monetary damages. If schools know that they may have to pay money damages if they do not comply with the statute, they are more likely to implement the statute diligently. The provision also ensures that students who have been harassed will be compensated for the danages they sustained.

In the next Part, I compare the proposed statute to existing laws. This comparison illustrates the differences between the proposed statute and existing laws, demonstrates how the proposed statute would be applied, and shows in what respects the proposed statute fills current gaps in protection.

\section{$\mathrm{V}$}

"Based on Sex" and "Based on Sexual Orientation" VERsus the Proposed Statute

Even though discrimination against lesbians and gay men is sex discrimination, courts are able to avoid this conclusion by incomplete analysis, often maintaining that the plaintiff's "sexual orientation" motivated the harasser and/or the defendant. Disingenuousness, careless legal analysis, or lack of understanding by courts has resulted in

161. Gary Remafedi, The Impact of Training on School Professionals' Knowledge, Beliefs, and Behaviors Regarding HIV/AIDS and Adolescent Homosexuality, $63 \mathrm{~J}$. SCH. HEALTH 153, 156 (1993).

162. See Treadway \& Yoakam, supra note 17 , at 355 . Ideally, of course, legislation would also prohibit discrimination against all school staff based on their sexual orientation. This Comment, however, focuses on discrimination against students. 
underinclusive interpretations of statutes designed to prohibit discriminatory decision-making. ${ }^{163}$ In essence, by changing the way that they frame the question presented by the case, courts manipulate outcomes to suit their own biases. 164

Although gay, lesbian, and bisexual students may make successful claims under Title IX for peer harassment either by using the "identically situated" argnment or the "sex stereotyping" rationale in conjunction with the prohibition of discrimination "based on sex," these efforts are likely to fail. Almost inevitably, courts neglect to inquire whether, in the case of a lesbian student, a male student with a female partner would be similarly harassed. Instead, courts superficially deem such harassment to be based on sexual orientation rather than sex and therefore not actionable. Title VII's and Title IX's disparate treatment model, and its requirement that conduct be "based on sex," which sexual harassment standards incorporate, allow courts to engage in faulty analysis. For this reason, Title IX's "based on sex" language presents a substantial obstacle to queer students who wish to sue under the statute. Baehr may provide some hope that courts will begin to issue more thoughtful and legally correct opinions, ${ }^{165}$ but the bulk of precedents undoubtedly serve as barriers to such developments.

By specifically stating that "[h]arassment or physical abuse based on sexual orientation is undertaken on the basis of sex," section 1(b) of the proposed statute prevents courts from replicating prior analytical errors. Concededly, the proposed statute could simply ban discrimination based on sexual orientation and achieve the same iminediate results. However, the proposed statute is preferable because it acknowledges that sexual orientation discrimination is sex discrimination, sending a clear message to courts to reverse their legal analysis. When statutes separately enumerate "sex" and "sexual orientation" as characteristics on which schools may not make decisions, they reinforce the false distinction between sexual orientation discrimination and sex discrimination. In contrast, the proposed statute may help courts to undertake more accurate analyses of sex and sexual orientation discrimination cases by bringing the overlapping nature of these "two kinds" of discrimination to the courts' attention.

However, even if courts recognized that sexual orientation discrimination is sex discrimination, statutes such as Title IX, which bans sex-based discrimination in education, would still provide victims of sexual orientation harassment with only a partial remedy. As the foregoimg sections discuss, the "but for" test requires not only that the

163. See Valdes, supra note 127, at 26-27.

164. See Marcosson, supra note 127, at 5-6.

165. See supra notes 133-134 and accompanying text. 
harasser and/or school choose their courses of action "because of" the victim's sexual orientation, but also demand that the victim prove that fact. For example, in some jurisdictions, if a student harassed both male and female classmates, the school might not be obligated to provide protection because this "equal opportunity" harassment would be treated as proof that the victim's sex did not motivate the harasser. ${ }^{166}$ As a result, even courts that view sexual orientation discrimination as sex discrimination are limited by Title VII's "based on sex" language.

Moreover, students, in contrast with employees, may encounter special difficulties in using a "based on sex" test. Specifically, Title IX's "based on sex" language may prove more problematic than the same language in Title VII in regard to establishing school district liability. The Petaluma court had little difficulty incorporating wholesale Title VII theories of liability to the Title IX context. ${ }^{167}$ That court held that as long as the harasser picked his victim based on her sex, and the school district knew or should have known of the harassment, there was a sufficient basis for liability on the part of the school district. However, the Fifth Circuit has placed an extraordinary evidentiary burden on Title IX plaintiffs, intinating that they must demonstrate that the school district had actual notice of complaints from both male and female students but only responded to the coinplaints from one of the groups. ${ }^{168}$

In jurisdictions with stringent standards for showing "intentional discrimination" on the part of the school, schools might try to argue that they failed to stop the use of sucli terms as "faggot" and "dyke" not because their intent was to provide less protection to homosexual students, but because those terms have "no reference to homosexuality; [instead,] it's just a name that kids call each other."169 Alternatively, schools may fail to respond to complaints simply out of mere negligence, lack of staff, or indifference. They may also claim that they failed to respond for these reasons because negligence and indifference constitute a sufficient legal defense in some jurisdictions. Thus, in the Fifth Circuit, where actual and/or constructive notice of sex-based harassment is an insufficient basis for liability, these explanations for inaction would be perfectly acceptable and successful defenses.

166. Compare Prescott v. Independent Life \& Accident Ins: Co., 878 F. Supp. 1545, 1551 n.6 (M.D. Ala. 1995) ("II]f a supervisor, male or female, created a hostile environment for all of the employees, this would not technically violate Title VII. There would be harassment, but it would not be based on gender."), with Chiapuzio v. BLT Operating Corp., 826 F. Supp. 1334, 1337 (D. Wyo. 1993) (reasoning that "equal harassment of both genders does not escape the purview of Title VIr").

167. See Doe v. Petaluma City Sch. Dist., 949 F. Supp. 1415, 1427 (N.D. Cal. 1996).

168. See Rowinsky v. Bryan Indep. Sch. Dist., 80 F.3d 1006 (5th Cir.), cert. denied, 1 I7 S. C. 165 (1996).

169. Savin-Williams, supra note 19 , at 14 (explaining rationale that some parents and teachers use im not stopping harassment). 
Another reason why using a broader standard than a "but for" test is particularly necessary in the school setting is that, in contrast to employees, students may be more susceptible to peer pressure and may not even be sure themselves what motivates their conduct. For example, students may simply join in the harassment of a student whom classmates have already targeted. The student who originally began the harassment may have done so because of the target student's sexual orientation, but others may join in simply as a result of peer pressure or to imitate other students' behavior. One student admitted that "even though he had no problem with gays and lesbians, he'd have a hard time resisting his peers if they were bothering one."170

An additional problem is the student who is himself gay but nevertheless harasses other queer students in order to deflect suspicion about his own sexual orientation. ${ }^{171}$ In this example, the student is harassing other students "based on" their "sex" because this method of harassment best serves his ultimate goal of keeping his own sexual orientation a secret. Nonetheless, it is probably overly optimistic to think that in this (and many other) situations, a court can truly know what motivates harassment. Under the proposed statute, a court need not determine motivation in this context to provide the victim with relief.

A further example is a case in which male students called a female student "lesbian", "prostitute", "retard", "scum", "bitch", "whore", "ugly dog faced bitch", and physically abused her.172 Would a court that does not accept sexual orientation discrimination as sex discrimination perceive this to be the latter or the former? The defendant might argue that it was neither and that instead, the male students were using derogatory terms because they simply did not like the student, having nothing to do with her gender or her sexual orientation. In this situation, it is difficult for a plaintiff to prove that she was harassed "because of her sex".

Section 1(a) of the proposed statute contains none of the aforementioned difficulties. Instead of focusing on the motivations of the harasser and school, it allows plaintiffs to state a claim regardless of whether the victim's sexual orientation was the reason for the harasser's or school's course of conduct.

170. Nancie L. Katz, Massachusetts Urges Sensitivity to Gay Kids: Plan May be First Statewide Effort to Fight Harassment in Schools, DALLAS MORNING NEWS, July 11, 1993 at $12 A$.

171. See CHANDLER, supra note 31, at 54 (telling story of gay male student who joined with his classmates in calling his boyfriend "fag" in order to protect his own reputation); Treadway \& Yoakam, supra note 17, at 353 (explaining that in order to hide their own sexual orientation, queer students will sometimes "tell 'fag' jokes or ridicule others who they perceive to be gay" or may even physically assault other lesbian, gay, and bisexual students).

172. Bruneau v. South Kortright Cent. Sch. Dist., 935 F. Supp. 162, 166 (N.D.N.Y. 1996). 
Finally, although sections 1(a) and 1(b) may appear redundant at first glance, they are not. While section (1)(a) remedies most of the problems inherent to prior legislative models that contain an intent requirement, both sections (1)(a) and (1)(b) are needed to ensure that school districts appropriately address harassment of queer students. Examples of the various types of harassment that occur in schools will help demonstrate why both sections are necessary. First, suppose the harasser targets students without regard to sexual orientation, or simply joins other students who are attacking a classmate, or repeatedly tells vicious "jokes" about gay students to his friends loudly enough so that everyone else in the lunchroom hears them. Assume that the school fails to remedy the conduct out of negligence, rather than because of the targeted student's sex. Even if the sex of the victim did not motivate the harasser's or the school's (in)action, section (1)(a) nevertheless holds the school liable. Second, assume that a student physically abuses another student because of the target student's sexual orientation without verbally indicating his motivation. ${ }^{173}$ Section (1)(b) requires the school to remedy the student's discriminatory conduct.

In the next Part, I discuss why it is appropriate that the proposed statute goes beyond the limited reinedies provided by the "but for" test. This Part explains why the proposed statute is justified in adopting a comprehensive approach to sexual orientation harassment and in imposing liability regardless of the motivational factors that lay behind the harasser's and/or school's motivation.

\section{VI}

\section{JUSTIFICATIONS}

The proposed statute imposes slightly more responsibility on schools than do more traditionally worded statutes that prohibit discrimination only when it is based on sexual orientation. This Part examines why this increased responsibility is justified.

\section{A. The Moral Imperative to Protect Young People's Lives}

The proposed statute requires schools to act to remedy harassment when they know or reasonably should know of harassment. This is essentially the same requirement that Title VII imposes on employers. ${ }^{174}$ Neither the proposed statute nor Title VII requires plaintiffs to show that the institutional defendant itself failed to remedy the harassment

173. This scenario raises the question of how the school would know that this is discriminatory conduct if the student does not offer any verbal indication. The school might know if, for example, the student only abuses students who are beheved to be gay.

174. See EEOC v. Hacienda Hotel, 881 F.2d 1504, 1515-16 (9th Cir. 1989). 
because of animosity toward the victim's sex. Under both statutes, mistake and indifference fail as defenses.

However, the proposed statute does eliminate one barrier to liability that Title VII erects. Under Title VII, an employer will only be liable if the harasser picked his victim based on the victimi's sex; the proposed statute contains no such limitation. The extra burden that schools would face because of this difference is slight. The more stringent standards under the proposed statute relate only to the harasser's state of mind. The comparatively greater requirements under the proposed statute are not the result of holding schools to a higher level of care or knowledge than employers face under Title VII. Under both statutes, the requisite standard for liability is actual knowledge of the harassment or knowledge that could have been gained in the exercise of reasonable care. Under both statutes, the institutional defendant need only take reasonable steps to remedy the harassment to avoid liability.

The slightly increased burden that schools would face under the proposed statute is justified by the extreme negative effects of peer sexual orientation harassinent. A student's ability to obtain relief from sexual orientation harassment should not hinge on judicial perceptions of the school's or harasser's motivations. Because lives are at stake, it is appropriate to impose an affirmative duty on schools to take reasonable steps to remedy sexual orientation harassinent even if school administrators theinselves possess no animosity toward gay, lesbian, and bisexual students.

The proposed statute forces schools to accept additional responsibilities. However, schools already accept the responsibility to safeguard students. Adolescents inust attend some sort of school and often have little choice in deciding which school they will attend. 175 "The institution serves as the parent and the student's 'home away froin home' for seven or more hours of the day, and generally legislators have adopted protectionist and paternalistic laws to protect those of school age."176 Thus, schools already have a responsibility to provide a safe environment, ${ }^{177}$ which requires more than simply refraining from invidious discrimination.

175. See Dennis \& Harlow, supra note 17, at $451 \mathrm{n} .21$ ("Laws require school-age children to attend some permissible school, as defined by statute, in every state except Mississippi."); Monica L. Sherer, No Longer Just Child's Play: School Liability Under Title IX for Peer Sexual Harassment, 141 U. PA. L. REV. 2119, 2157 (1993) ("Education . . . is mandatory. Indeed, most children are required to attend a partieular district public school. Transferring from one pubhic school to another is often diffieult. Furthermore, transferring to a private school is often not a viable option because of the costs of such an education.").

176. JoAnn Strauss, Peer Sexual Harassment of High School Students: A Reasonable Student Standard and an Affirmative Duty Imposed on Educational Institutions, 10 LAW \& INEQ. I 163, 181 (1992).

177. See Dennis \& Harlow, supra note 17 , at 451 . 
Critics might bemoan a payout of money damages or the threat of incurring liability as an inappropriate use of taxpayer funds. However, if taxpayers are concerned with allocating funds to cornpensate victims, their best course of action is to becoine more involved with their community's schools. They may put pressure on school administrators to ensure that the proposed statute is appropriately enforced. Under this view, the potential for monetary damages could result in more community involvement with our schools.

Finally, if diligently implemented, the proposed statute imposes only a slightly increased burden on schools. The statute only requires the school to provide training and take reasonable steps to deal with those students who harass their peers. In light of the numerous lives that the proposed statute could improve and save, the slightly increased burden is amply justified.

\section{B. The Logic of Prior Civil Rights Legislation is Similar to That of the Proposed Statute}

The proposed statute is not alone in recognizing that actions undertaken with a benign purpose can be extremely destructive. Title VII's "disparate impact" model prohibits behavior that acts as a barrier to equal opportunity regardless of the behavioral motivation. ${ }^{178}$ In explaining the purpose behind the disparate impact cause of action, the Supreme Court stated that Congress's objective in enacting Title VII "was to achieve equality of employment opportunities and remove barriers that have operated in the past to favor an identifiable group of ... employees over other employees."179 The Court found that "[w] hat is required by Congress is the removal of artificial, arbitrary, and unnecessary barriers to employment."180 In sum, "good intent or absence of discriminatory intent does not redeem employinent procedures or testing mechanisms that operate as 'built-in headwinds' for minority groups and are unrelated to measuring job capability.... Congress directed the thrust of the Act to the consequences of employment practices, not simply the motivation." ${ }^{181}$ Like Title VII's disparate impact model, the proposed statute recognizes that at times when certain courses of conduct operate as barriers to achievement, it is appropriate to afford relief to those who are affected by the conduct.

Requiring plaintiffs to demonstrate that einployers acted on the basis of sex makes sense in soine contexts. For example, if an employer chooses to hire a male applicant instead of a female applicant, the

178. See International Bhd. of Teamsters v. United States, 431 U.S. 324, 335-36 n.15 (1977).

179. Griggs v. Duke Power Co., 401 U.S. 424, 429-30 (1971).

180. Id. at 431 .

181. Id. at 432 . 
employer may do so because the male applicant is more qualified. Most view that decision as one with overall positive consequences, including the reward of merit. If, however, what the employer requires of applicants bears no relation to performance on the job and operates to exclude most women-but not most men-from consideration for the job, there are no positive consequences. Likewise, only harm occurs when schools fail to remedy peer sexual orientation harassment. Unlike the disparate treatment requirement in the hiring context, little is to be gained by imposing an intent requirement in the school context. The proposed statute, like Title VII's disparate impact theory, utilizes standards that recognize these distinctions. The proposed statute recognizes that absence of discriminatory intent does not ensure a lack of harm and acknowledges the connection between sexual orientation harassment and negative consequences. For these reasons, it represents a comprehensive approach to student-to-student sexual orientation harassment that is in harmony with contemporary civil rights law.

\section{VII \\ Prospects for Passage}

Admittedly, the proposed statute seems somewhat unobtainable. Indeed, there have been numerous anti-gay initiatives in recent times, the most infamous being Colorado's unconstitutional "Amendment 2," through which voters of that state amended their constitution to prohibit any state governmental entity from adopting any rules or policies to prevent discrimination against gay, lesbian, or bisexual individuals. ${ }^{182}$ Some legislators have been particularly resistant to any movement toward a more tolerant atmosphere in schools. ${ }^{183}$ However, despite these attempts to limit or further intrude upon the rights of gays and lesbians, there have actually been a number of positive steps taken toward protecting gay, lesbian, and bisexual adolescents from discrimination.

As mentioned earlier, several states have enacted statutes that prohibit public schools from discriminating against students on the basis of sexual orientation. ${ }^{184}$ Moreover, numerous individual school districts have adopted anti-discrimination policies that provide protection to

182. See Romer v. Evans, 116 S. Ct. 1620, 1623 (1996) (quoting amendment and describing process through which state adopted it). The Court held that Amendment 2 violated the Equal Protection Clause of the United States Constitution. See id.

183. See Nan D. Hunter, Identity, Speech, and Equality, 79 VA. L. REV. 1695, 1713-14, 1714 $\mathrm{n.73}$ (1993) (describing state legislation on AIDS education that either prohibits any mention of homosexuality in an accepting hight or requires that programs teach that "homosexuality is not a lifestyle acceptable to the general public and that honiosexual conduct is a criminal offense under the laws of the state") (quoting ALA. CODE $\S 16-40 A-2(a)(8)(1992)$ ).

184. See supra note 93 . 
queer students. ${ }^{185}$ In some cities, agencies in charge of placing teenagers in foster homes seek to place queer teenagers in gay and lesbian households and "juvenile judges recognize the appropriateness of making such placements." 186 In the Los Angeles School District, a teacher developed "Project 10," a program ained at reducing the effects of antigay and lesbian discrimination. Project 10 began as a counseling program for youth, "consisting of education, school safety measures, human rights advocacy, drop-out prevention strategies, and use of community resources." 187 The program also sought to "heighten the school community's acceptance of and sensitivity to gay, lesbian, and bisexual issues." 188 Other schools throughout the nation have modeled programs after Project $10 .^{189}$

As these numerous programs demonstrate, it is possible to convince legislatures, school districts, and boards to adopt policies that protect gay, lesbian, and bisexual students. These examples suggest that the most successful strategy is one that focuses on the state or local level and involves both teachers and students. One person involved with implementing projects in the Los Angeles School District believes that if organizers had first approached the problem at the state level and attempted to obtam permission for implementing their plans, the district would not have started any of the programs due to state resistance. Consequently, she advocates starting projects on the local level. ${ }^{190}$

In Massachusetts, the bill to add "sexual orientation" to the antidiscrimination statute applicable to schools languished in committee for two years. ${ }^{191}$ When students became involved in lobbying for the bill's passage, the legislature finally enacted it, and the governor's chief secretary attributed its passage to the students' participation. The hundreds of students involved in the lobbying effort "told legislators emotional stories of feeling isolated and afraid at school... of being physically threatened, attacked and cursed at in class and in school hallways because of their sexual orientation."192 The students successfully "provided faces to Federal statistics that show an alarming rate of

185. See, e.g., Armstrong, supra note 44, at 89 (describing St. Paul Public School District's statement that prejudicial behavior toward gay and lesbian students will not be tolerated).

186. HAYDEN CURRYET AL., ALEGAL GUIDE FOR LESBIAN AND GAY COUPLES 3-30 (7th ed. 1993).

187. Virginia Uribe \& Karen M. Harbeck, Addressing the Needs of Lesbian, Gay, and Bisexual Youth: The Origins of PROJECT 10 and School-Based Intervention, J. HOMOSEXUALITY, Nos. 3/4, 1991, at 9, 18.

188. Id. at 11 .

189. See id.; Armstrong, supra note 44, at 87.

190. See Goldberg, supra note 43, at 126.

191. See Sara Rimer, Gay Rights Law for Schools Advances in Massachusetts, N.Y. TIMES, Dec. 8, 1993, at A18.

192. Id. 
suicide among gay and lesbian youth, as well as a high dropout rate."193 This example suggests that students themselves may be the most forceful advocates for change.

\section{CONCLUSION}

Current laws are insufficient to deal with sexual orientation harassment because of their limited scope and misguided judicial interpretations. In particular, current laws allow courts to render sex discrimination laws underinclusive because the statutory and constitutional provisions do not make it clear that sexual orientation discrimination is, in fact, sex discrimination. Additionally, because they contain an intent requirement, current laws are too narrow to deal with all of the types of sexual orientation harassment that cause harm. The severenegative consequences of peer sexual orientation harassinent detrimentally affects a considerable number of gay, lesbian, and bisexual students. Because of these severe effects, a broader statute, one that imposes an affirmative duty on schools to take reasonable steps to eliminate sexual orientation harassinent, is both urgently needed and fully justified.

193. Id. 